\title{
Indonesian smart schools: Their influence on the ability of information literacy on the biology field

\author{
Adhitya Amarulloh ${ }^{1}$, Endang Surahman ${ }^{2}$, Vita Meylani ${ }^{3,}$ * \\ Biology Education Department, Faculty of Teacher Training and Education, Universitas Siliwangi, \\ Indonesia \\ ${ }^{1}$ adhitya.amarulloh@outlook.com, ${ }^{2}$ e.surahman@unsil.ac.id, ${ }^{3}$ vibriovita@unsil.ac.id * \\ * Corresponding author
}

\begin{tabular}{l}
\hline ARTICLE INFO \\
\hline Article history \\
Selected paper from The $3^{\text {rd }}$ \\
Symposium on Biology Education \\
(Symbion), Yogyakarta-Indonesia, \\
August 31, 2019. Peer-reviewed \\
by Symbion Committee and \\
Editorial Board of Jurnal \\
Bioedukatika
\end{tabular}

Received September 26, 2019

Revised February 8, 2020

Accepted February 25, 2020

Keyword:

Digitalization

Information literacy

Learning reform

\begin{abstract}
Information literacy in the information society era is very important for every individual, especially for students to prevent misunderstandings and misconceptions. Digitalbased learning can influence on students' information literacy abilities. The purpose of the study is to look at the effect of digital-based learning (Indonesian Smart Schools) on students' information literacy abilities. This research was conducted from February to June 2019, at SMA Negeri 2 Tasikmalaya. The research method was a trueexperimental design with randomized pretest-posttest control group design. This study population was class X, amounting to 299 people, with cluster random sampling technique, the results were class X MIPA 1 (experimental) and X MIPA 5 (control). The information literacy research instrument uses a validated instrument from SAILS ${ }^{\circledR}$ (30 items). Based on the ANCOVA analysis at the significance level $(\alpha)=0.05$ and based on the comparison of the values gain, it can be concluded that there was an effect of digitalbased learning on students' information literacy abilities on Animalia material. Indonesian Smart Schools can be alternative digital learning to hone the ability of information literacy on Animalia material. Indonesian Smart Schools can be an alternative to digital learning to hone the ability of information literacy.
\end{abstract}

This is an open access article under the CC-BY-SA license.

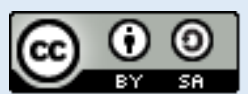

\section{Introduction}

Digital technology is not new to the millennial generation (Prensky, 2001), when compared with the 20th-century generation of digital media usage, and the need for digital information is increasing in the 21stcentury generation (OECD, 2005). The development of information technology to obtain information literacy starts from devices desktop limited in terms of space and ownership to devices mobile. Devices Mobile and the internet make accessibility of digital information easier and without space restrictions (Pedró, 2006). This has caused an increase in the ownership of cellular devices including cellphones and tablets among the world community over the past five years (Pew Research Center, 2019). Increased ownership of cellular devices is also directly proportional to their use, especially among children and adolescents. Since 2011 the use of mobile devices in children and adolescents has tripled with an average use of 2-3 hours (Lutze \& Waldhor, 2015). This has implications for the speed of information received by children and adolescents, including information that is not yet valid. Nevertheless, the development of digital information literacy is slow compared to the development of information 
communication technology (Duderstadt \& Womack, 2004). Therefore, the speed of information reception is in line with the development of information technology in society but is inversely proportional to the level of understanding of information literacy.

The increase in cellular ownership and use also has implications for the world of education which is also undergoing reforms of learning through mobile learning which is used for various needs of the learning process especially as a source of learning (Crompton, 2013). So, the speed of receiving this information must be balanced by the information literacy of students so there is no misinformation and misconception in learning. Mastering information literacy is thought to create skills-based literacy (Hasugian, 2008). There are skills that included in this skill, such as the ability to search for information, select information sources intelligently, assess and sort information resources, use, and present information ethically (Webber \& Johnston, 2017). This mastery is important so that misconceptions do not occur which in turn can inhibit meaningful understanding and good performance in lessons and are one source of learning difficulties (Maesyarah, Jufri, \& Kusmiyati, 2015). In addition, digital information that is easily accessed by students is in fact not always true and valid information. Therefore, sufficient information literacy is urgently needed in this era to be trained in students in schools. This is needed to reduce misunderstanding in receiving information from digital devices. So, students can filter the information that they get from digital technology.

Nowadays, digital technology is not only used as a learning resource but also as a medium of learning and learning evaluation including the Computer-Based National Examination (UNBK), e-report cards, and college entrance selection through the Computer-Based Writing Test (UTBK) (Munir, 2017; Suprapto, Suharsono, Chaidir, \& Ali, 2019). In fact, the use of Blended Learning (BL) has become a widely used learning method (Dziuban, Graham, Moskal, Norberg, \& Sicilia, 2018). This condition indirectly causes students to get more information presented by the internet. Thus, good information literacy is needed to minimize misconceptions in learning, especially since teachers as facilitators cannot fully provide sufficient elaboration to be able to provide a clearer understanding. The fact is the literacy ability of students in Indonesia according to the Program for International Students Assessment (PISA) consistently is ranked below (Fauziah \& Lestari, 2018). In fact, the ability of information literacy is an indication of the way students obtain and process information (Andretta, 2005). The ease of finding information in the digital age has caused students to rely heavily on search engine technology on the internet without the sorting and understanding of information obtained (Rattanawongsa \& Koraneekij, 2015). As a result of these conditions, the information obtained can provide a different and wrong understanding so that misconceptions arise.

Considering the importance of information literacy and its increasingly rapid technological development in the learning process some schools already use digital-based applications (android) such as the use of e-learning (Ramdani, Rahmat, \& Fakhruddin, 2018), blended learning (Indriani, Fathoni, \& Riyana, 2018) in managing class and learning process. However, the use of e-learning and blended learning has several shortcomings including (i) the material presented is not sufficient for students' needs, (ii) when there are difficulties in learning it is difficult to ask for solutions to teachers, and (iii) the platforms used tend to require good device specifications (Szadziewska \& Kujawski, 2017). So that the use of these two methods still requires improvements

The Indonesian ${ }^{\circledR}$ Smart School Application has a feature to create digital libraries for educators so that they can upload learning materials, articles and ebooks independently so that students can get more information, wider and more credible because of the information provided directly from educators (Muqarrobin \& Kuswanto, 2016). This can prevent misconceptions and can train students to assess sources and information that is valid and credible. In addition, the Indonesian ${ }^{\circledR}$ Smart School Application does not require high specification devices so it is more affordable to be used in many schools. Nevertheless, this application still has flaws in terms of the use of new evaluations that can provide the right or wrong option without giving an explanation. Even so, the use of this tool can make it easier for students to learn material digitally where the information is directly provided by the teacher so that the validity 
and credibility of the information were clear. In fact, evaluation and assessment can be accessed at any time so that the learning process can be more effective (Kaustubh A., Yogita H., Mayuri V., \& Pooja G., 2017). So that the Indonesia Smart School Application can streamline the learning process because it can be repeated anytime and anywhere, without having to face-to-face. Therefore, the aim of this study is to evaluate the use of the SmartPart Indonesia ${ }^{\circledR}$ School Application as an alternative to digitalbased learning media and its effect on students' information literacy abilities in learning biology.

\section{Method}

This study used the method TrueExperiment with Randomized Pretest-
Posttest Control Group Design. This research method used based on the assumption that the population was homogeneous so that the sampling technique used also uses probability sampling, namely cluster random sampling (Fraenkel, Wallen, \& Hyun, 2018). The population of this study was chosen based on the students of Class X MIPA SMA 2 Tasikmalaya consisting of 299 people, the sampling technique used was cluster random sampling. Two research classes were selected, namely class X MIPA 1 as an experimental class and class X MIPA 5 as a control class. The use of media in the experimental class uses the Indonesian ${ }^{\circledR}$ Smart School application shown in Figure 1. Whereas the control class only used media PowerPoint. The material used is Animalia material.
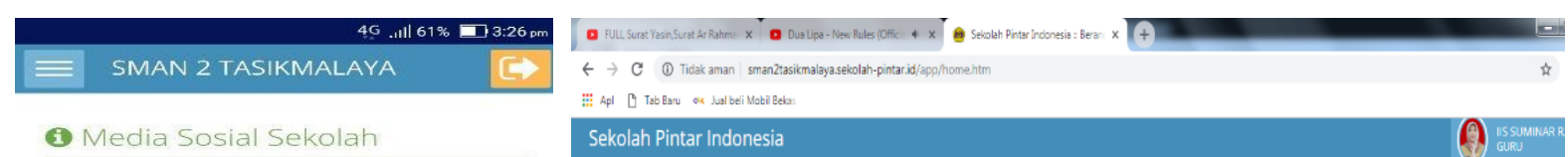

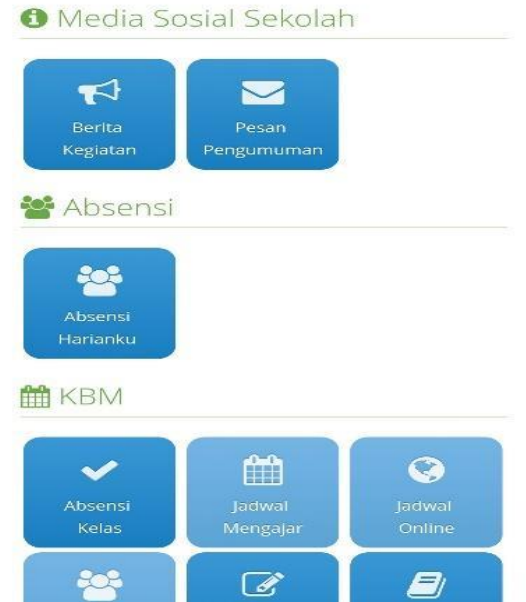

(a)

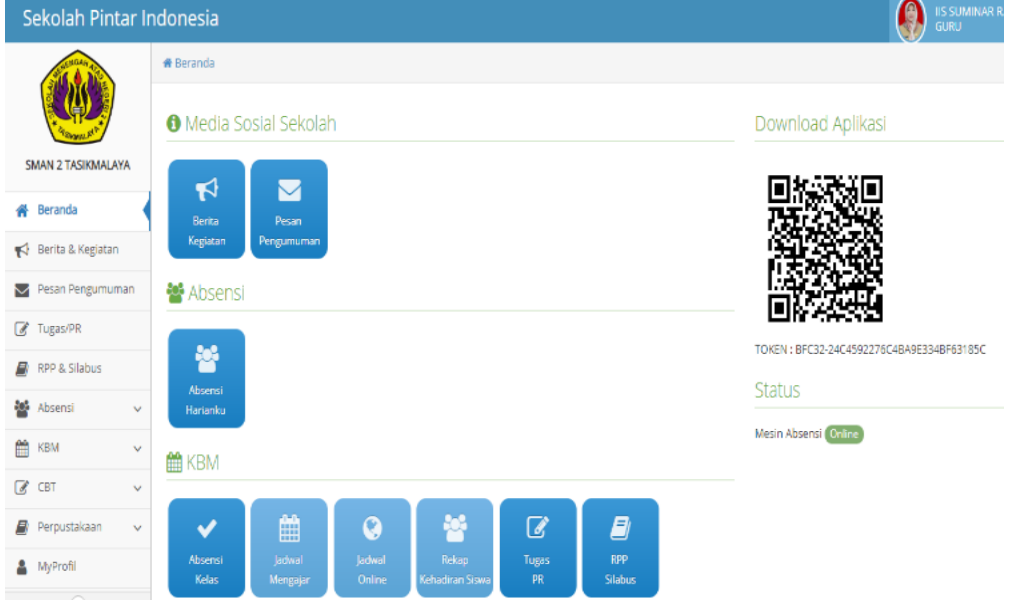

(b)

Figure 1. (a) Display of Mobile Applications in Indonesian ${ }^{\circledR}$; (b) Smart Display of Smart Schools Desktop Schools Application

Data collection was carried out starting from November 2018 - April 2019, data collection techniques using observation techniques, unstructured interviews, literature studies, and tests. The instrument used was a multiple-choice test, an expert validated instrument from Kent State University in the United States in the Standardized Assessment of Information Literacy Skills (SAILS Project) project in 2012. The indicators assessed were developing a research strategy, selecting finding tools, searching, retrieving sources, evaluating sources, and documenting sources (Table 1) (Carrick Enterprises, 2012).
Table 1. Information Literacy Instrument Lattice

\begin{tabular}{lll}
\hline \multicolumn{1}{c}{ Indicator } & No. Problem & Amount \\
\hline $\begin{array}{l}\text { Developing a } \\
\text { research strategy }\end{array}$ & $1,2,3,4,5$ & 5 \\
$\begin{array}{l}\text { Selecting findings } \\
\text { tools }\end{array}$ & $6,7,8,9,10$ & 5 \\
Searching & $11,12,13,14$, & 5 \\
& 15 & \\
Sources & $16,17,18,19$, & 5 \\
retrieving & 20 & \\
Evaluating & $21,22,23,24$, & 5 \\
sources & 25 & \\
$\begin{array}{l}\text { Sources } \\
\text { documenting }\end{array}$ & $26,27,28,29$, & 5 \\
Total & 30 & \\
\hline & 30 & \\
& (Carrick Enterprises, 2012)
\end{tabular}


Research data were analyzed with the help of IBM SPSS 23, analysis prerequisite tests include normality tests with the Kolmogorov-Smirnov test and homogeneity tests with the test Levene at the significance level $(\alpha)$ 0.05. Hypothesis testing using the ANCOVA test at the significance level $(\alpha)$ 0.05 with the help of IBM SPSS 23.

\section{Results and Discussion}

Research data were obtained through pretest and posttest, the entire research data is presented in Table 2 .

Table 2. Statistics literacy score

\begin{tabular}{|c|c|c|c|c|c|c|}
\hline Statistics & $\begin{array}{c}\text { Information } \\
\text { Pretest } \\
\text { Information } \\
\text { Literacy } \\
\text { (Experiments) }\end{array}$ & $\begin{array}{c}\text { Pretest } \\
\text { Literacy } \\
\text { (Control) }\end{array}$ & $\begin{array}{c}\text { Information } \\
\text { Posttest } \\
\text { Information } \\
\text { Literacy } \\
\text { (Experiment) } \\
\end{array}$ & $\begin{array}{c}\text { Posttest } \\
\text { Information } \\
\text { Literacy } \\
\text { (Control) }\end{array}$ & $\begin{array}{c}\text { Gain } \\
\text { (Experiment) }\end{array}$ & $\begin{array}{c}\text { Gain } \\
\text { (Control) }\end{array}$ \\
\hline Maximum & 18.00 & 17.00 & 26.00 & 20.00 & 16.00 & 8.00 \\
\hline Minimum & 10.00 & 7.00 & 15.00 & 9.00 & 1.00 & 1.00 \\
\hline Range & 8.00 & 7.00 & 11.00 & 11.00 & 15.00 & 7.00 \\
\hline Average & 13.59 & 11.84 & 21.41 & 14.24 & 7.95 & 2,27 \\
\hline $\begin{array}{l}\text { Standard } \\
\text { of }\end{array}$ & 2.339 & 2.662 & 3.40 & 2.73 & 4.00 & 1.85 \\
\hline Deviation & & & & & & \\
\hline Variance & 5.470 & 7.084 & 11.58 & 7.48 & 15.99 & 3.42 \\
\hline
\end{tabular}

Prerequisite test analysis results were presented in Table 3, the data normality test Liliefors research shows all groups. The data has a significance of $>$ sig. (0.05), so that all data has been taken from a normally distributed population. Homogeneity test results of research data show the same thing, namely the significance of the count $>$ sig. $\alpha$ (0.05) so that the variance of homogeneous data groups.

Table 3. Prerequisite test results analysis

\begin{tabular}{clcl}
$\begin{array}{c}\text { Prerequisite } \\
\text { test }\end{array}$ & \multicolumn{1}{c}{$\begin{array}{c}\text { Data } \\
\text { (information literacy) }\end{array}$} & Sig. & \multicolumn{1}{c}{ Conclusion } \\
\hline \multirow{3}{*}{ Normality } & Scores pretest experiment class & 0.088 & Data normally distributed \\
(Liliefors) & Scores pretest control class & 0.200 & Data normally distributed \\
& Score posttest experimental class & 0.066 & Data normally distributed \\
& Score posttest control class & 0.079 & Data normally distributed \\
Homogeneity & Scores pretest & 0.290 & Variance Data homogeneous \\
& Scores posttest & 0.086 & Variance Data homogeneous \\
\hline
\end{tabular}

Based on data analysis prerequisite test parametric studies meet the rules, then test the hypothesis using ANCOVA test is assisted with IBM SPSS 23 applications. ANCOVA test results are presented in Table 4.

Table 4. ANCOVA test results with SPSS assistance

\begin{tabular}{|c|c|c|c|c|c|c|}
\hline \multicolumn{7}{|c|}{ Tests of Between-Subjects Effects } \\
\hline \multirow[b]{3}{*}{ Source } & \multicolumn{4}{|c|}{ Dependent Variable: Post Test LI } & & \multirow[b]{2}{*}{ Partial Eta } \\
\hline & Type III Sun & & Mean & & & \\
\hline & Squares & $d f$ & Square & $\boldsymbol{F}$ & Sig. & Squared \\
\hline$\overline{\text { Corrected Model }}$ & $1057.648^{\mathrm{a}}$ & 2 & 528.824 & 65.594 & 0.000 & 0.649 \\
\hline Intercept & 332.250 & 1 & 332.250 & 41.212 & 0.000 & 0.367 \\
\hline PreLI & 115.810 & 1 & 115.810 & 14.365 & 0.000 & 0.168 \\
\hline Class & 659.086 & 1 & 659.086 & 81.752 & 0.000 & 0.535 \\
\hline Error & 572.406 & 71 & 8.062 & & & \\
\hline Total & 25176.000 & 74 & & & & \\
\hline Corrected Total & 1630.054 & 73 & & & & \\
\hline
\end{tabular}

Based on Table 4 it can be concluded that there is an influence of the use of Android-based application media on the ability of students' information literacy (shown in the value of sig. Count in the column PreLI $0.000<$ sig. $(\alpha)$ 0.05). And there is a moderate and positive relationship between the learning process 
of Android with information literacy ability seen from the regression coefficient number of 0.649 (Dancey \& Reidy, 2011). So that the role of Android-based media applications by $64.9 \%$ in terms of increasing the ability of students' information literacy.

Hypothesis testing results were strengthened by the results of information literacy tests. Figure 2 shows that there was an increase between the score pretest (before giving treatment) with the posttest (after giving treatment).

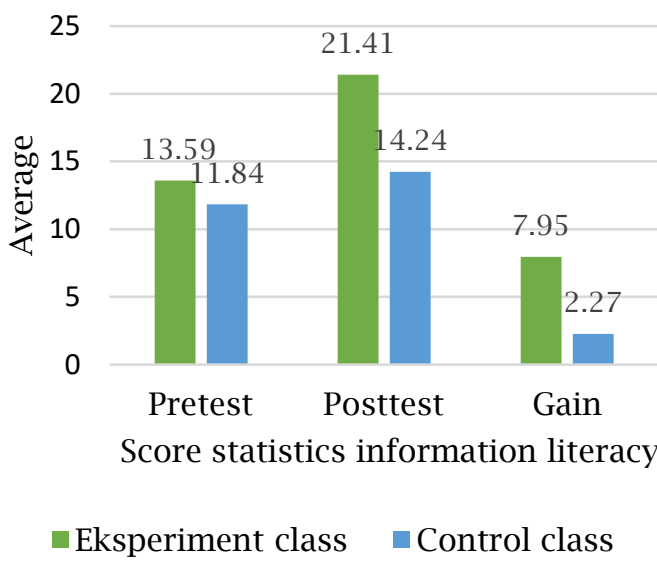

Figure 2. Average Learning Outcomes and Literacy Information Score from Experimental and Control Class

Figure 2 shows there was an increase in the ability of information literacy in Animalia material both in the experimental and control classes, from the graph the increase in the experimental class is higher than the control class, and it can be seen from the values gain between the experimental and control classes that have a significant difference. This can be an indication that the learning media based on Android applications can improve the ability of information literacy better than conventional media. Understanding mobile learning according to experts "Mobile learning is a combination of E-Learning with Mobile Computing (mobile-based computing) provides resources that can be accessed anywhere with the best search system, full of interaction and get full support in terms of the effectiveness of learning and assessment" (Crompton, 2013; Kaustubh A. et al., 2017; Lin, Deng, Hu, \& Tsai, 2019; Sung, Lee, Yang, \& Chang, 2019). Mobile-based learning can be categorized as learning without limits of space and time in terms of the environment, resources, and learning interactions (Evans, 2008; Sharples,
2000). Increasing the assumptions and theoretical basis for the use of mobile learning is increasingly widespread and shows a change in the learning atmosphere in the form of increased learning independence of students or self-regulated learning (Bernacki, Greene, \& Crompton, 2020; Danish \& Hmelo-Silver, 2020). Referring to the expert opinion, the effectiveness of learning and assessment by using mobile learning through media based on Android applications can be increased because it can be done anywhere and anytime without being limited by space and time limitations.

So that the conclusions from the analysis conducted have a directly proportional relationship with expert opinion, with the increased opportunity for students to get teaching materials that are appropriate and easily accessible to make students have greater freedom in learning. This is in line with the opinion of Arsyad (2016), that the use of the internet or the digital world expands learning opportunities for students, they not only get one learning material but a lot of learning material so that they are able to enrich information for students. The use of the Indonesian Smart School application for students can make the value of the use of smartphones they have more relevant to their main duties as students, the use of digital media here as a form of scaffolding (Wood, Bruner, \& Ross, 1976) and has been tested with effective results (Aleven, McLaughlin, Glenn, \& Koedinger, 2017), then this can minimize the misuse of features smartphone among students.

This was also supported by the level of activeness and independence of students in the experimental class higher than the control class, referring to the task journal, discussion activities, and class presentations. As well as the ability of the experimental class in using and sorting information sources to do LKPD better than the control class, the experimental class no longer uses sources from Blogspot, WordPress, and Wikipedia that have not been validated. Students in the experimental class tend to use books, online articles and $e-b o o k s$ to be used as sources. And they can already include citations from the sources used, even though the citations used are still very simple. The use of mobile media makes it easier for students to determine sources with proper supervision and direction from educators, can optimize 
mobile media to find learning resources (Phillips, Van Epps, Johnson, \& Zwicky, 2018). This is also in line with research conducted by Muyaroah and Fajartia (2017) that learning by using Android learning media can increase the effectiveness of learning characterized by increasing the activeness and independence of students in learning. Sholeh, Sutanta, and Sulistyowati (2017), revealed the use of Android in learning has increased students' interest in learning and the applications used are able to convey information well and are easy to use.

Then the results of this study are in line with the results of research from these researchers. In this case, the learning process by using Android-based learning media in the experimental class was able to provide freedom for students to choose learning resources that are on the application page because they can choose the source of information that suits their needs. This makes students have an awareness of their needs for teaching materials or information because they are faced with a variety of sources that can be chosen by students, this was very suitable for increasing information literacy among students and was encouraged by the dynamics of an improved approach to information and science (Sadioğlu, İpek, \& Derman, 2009). Because the characteristics of people with information literacy will always be needed with learning activities without being bound by space, time, and age. So that the impact can create individuals who learn throughout life (Lifelong Learning), because information literacy was the key to life-long learning (Polat, 2005, as cited in Sadioğlu et al., 2009) because with the need for information makes students able to determine what they are interested in their learning (Yetkin and Dascan, 2006, as cited in Sadioğlu et al., 2009).

In addition, students in the experimental class can process the information they get from the source and include information that is relevant or just what they need, no longer copy and paste directly. This happens because they were faced with a lot of resources with limited time, so students select every information available to reconstruct the answers more meaningfully. Students also tend to look for sources outside of the sources that have been provided in the application, this can be an indication that they have a higher level of need for information to solve an existing problem. Furthermore, today's learning Information Literacy based on digital has become a trend of its own, such as the use of learning instruction information literacy that was online (Maddison, Doi, Lucky, \& Kumaran, 2017), analysis of characteristics (Fernández-Ramos, 2016; Saunders, 2018; Yang \& Chou, 2014) or the benefits of information literacy (Anderson \& Wilson, 2009; Haber \& Mitchell, 2017) are all done with digital and online systems. As well as seen from the ease of accessing information and being able to stimulate independent learning into a positive impact of digitalization of information literacy learning (Fernández-Ramos, 2019).

Referring to the independence in learning conducted by students can be an indication that information literacy has grown in the character of students, this was explained by the American Library Association (ALA) (Hisle \& Webb, 2017) that literacy skills information is the ability that makes an individual know when he needs information, how to obtain, assess and use it effectively. So independence in learning and the desire to learn that still arises outside the classroom can be one of the characteristics that students already have information literacy abilities.

Based on the ANCOVA test analysis results, the results of observations in learning, assignment journals, and relevant research results, it can be concluded that the learning media based on Android applications has an influence on the ability of students' information literacy in learning Biology in Animalia material. As for the average literacy in the experimental class, the information can be seen in Figure 3.

The average score of information literacy in Figure 3 increase, judging from the pretest to posttest stock. Of the six information literacy indicators that have the highest average posttest and gain in the ability to develop a research strategy (the ability to plan a project), it is also illustrated in the learning process where students in the experimental class have the ability to compile data in journals with good and able to coordinate group and class discussions well. This is reinforced by the statement of Hisle and Webb, (2017) that the ability to develop a research strategy will grow in tandem with the frequency of individuals doing something. In the process students in the experimental class compile a journal at each meeting from the first semester, so 
students have more experience than the control class in terms of preparing and planning the journal work. Then the ability to develop a research strategy of experimental class students has been slowly embedded.

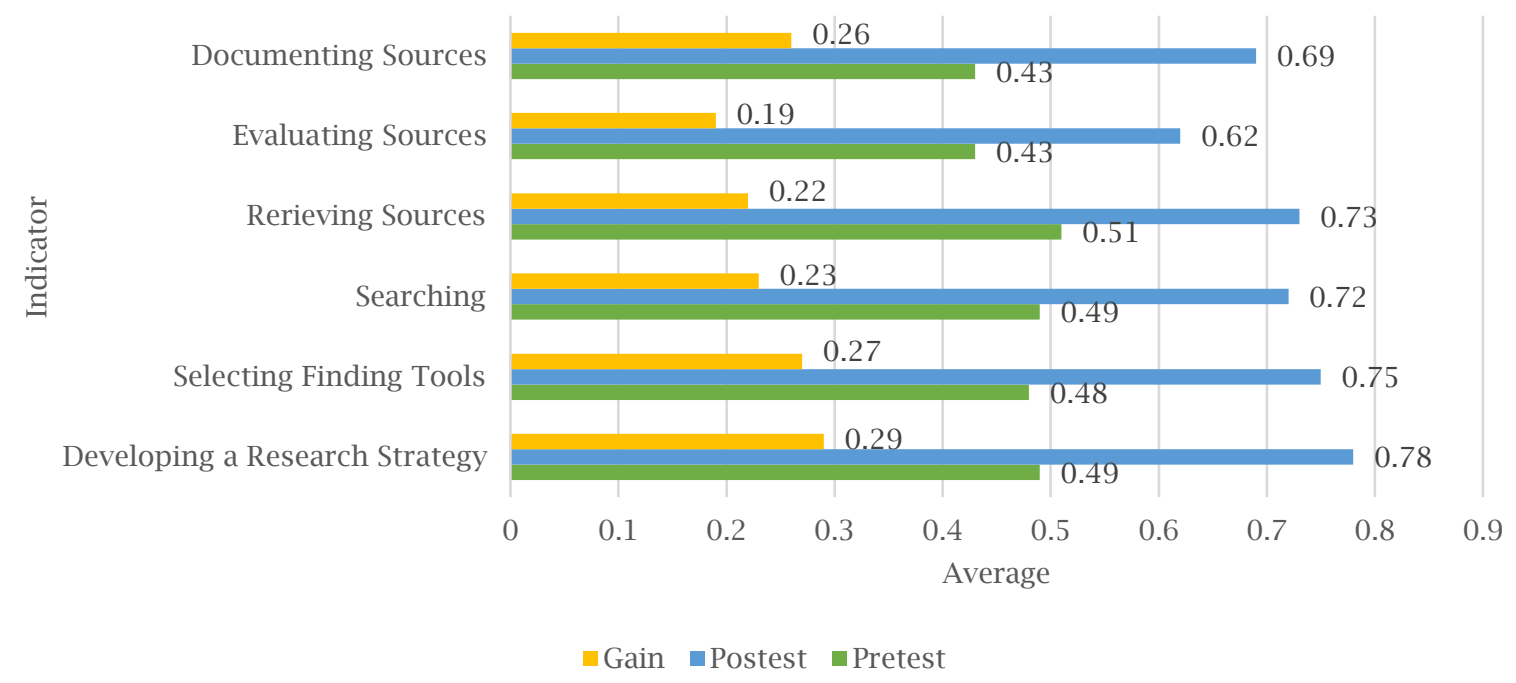

Figure 3. Average score information literacy experiment class

The lowest average score on the ability to sources evaluate (assessing the source), this was consistent with the results of the assessment of students' data findings in journals, students still often use sources that are less suitable and not sources that credible and educators were sometimes difficult to determine what will use. In line with tests conducted in Carrick Enterprises, (2012) showing the lowest results on the indicator evaluating sources with an average score of 476, it is further explained that the ability to assess sources is very closely related to students' understanding of the content of the information, at least high reasoning ability is needed to be able to judge a source. In line with this view, the experimental class sample is in the age range of 15-16 years, still lacks sharp reasoning to assess information. So, students are more likely to use all kinds of sources that they find in the Google search engine without first referring to the source credibility. But the use of resources in the experimental class has improved quality, students no longer use sources are WordPress, Blogspot, and Wikipedia not validated.

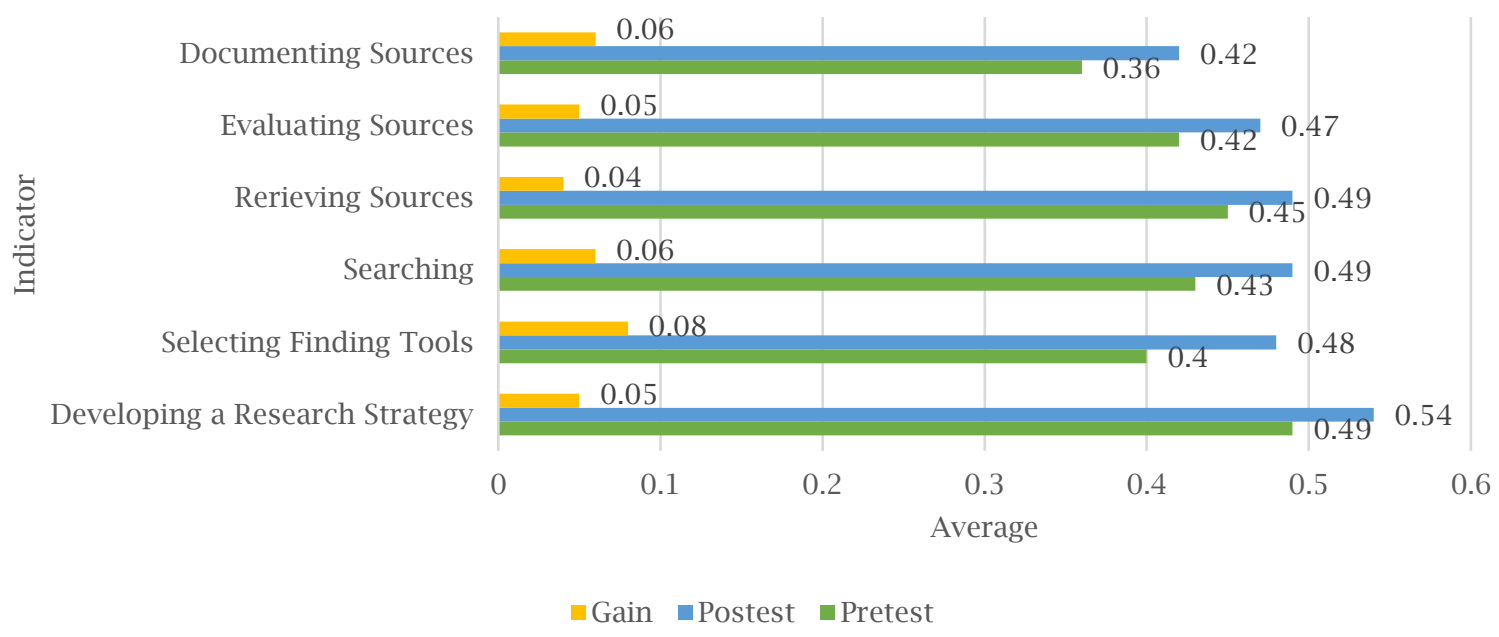

Figure 4. Average control class literacy score 
Information In Figure 4 contains the average data control class information literacy score, there are several indicators that have an increase even though it does not increase far but in the ability of Retrieving Sources (get the source) is the lowest indicator. This is possible because students are not yet accustomed to looking for relevant and credible data sources because in their learning participants are less required to have these abilities. For the highest increase in the indicator Selecting finding tools, when compared with the experimental class scores it has a very significant difference, but compared to the increase in other indicators in the control class, the indicator Selecting finding tools has the highest increase. This is possible for students in the control class literacy with a variety of tools to find information, especially smartphones, laptops, and the internet, and often use it so that this indicator has increased. This is consistent with the presentation of the results of Carrick Enterprises, (2012) that the more often a person is introduced to information literacy, then that person will have the ability to search, process, and assess information or sources. So, this is in line with the results of research conducted, because students in the control class are not familiar with the activities of searching, processing and assessing information, so they have low information literacy skills.

\section{Conclusion}

Digitalization is becoming increasingly evident in the 21st century, one form of adjustment to the digital era is done by using Android-based digital media through the Indonesian Smart School application as a learning medium. Showing the results there is an influence of the use of Androidbased application media on the ability of Information Literacy in Biology learning in Animalia material, and there is a moderate relationship between the increase in the ability of Information Literacy of students by $64.9 \%$. The factor that increases it is the Indonesian Smart School application media. The increase was also shown in the gain score, the experimental class had a higher score with the most prominent indicator being the indicator developing a research strategy (the ability to plan a project) and the lowest indicator evaluating sources (assessing the source). And the use of the Indonesian Smart School application media can increase the activeness of students in the classroom and stimulate independent learning. So, based on the results of research and findings in the field, the Indonesian Smart School can be an alternative in digital/online-based learning to train and hone the ability of students' Information Literacy, especially in learning Biology.

\section{References}

Aleven, V., McLaughlin, E. A., Glenn, R. A., \& Koedinger, K. R. (2017). Instruction based on adaptive learning technologies. In R. E. Mayer \& P. A. Alexander (Eds.), Handbook of research on learning and instruction (2nd ed.). Google Books

Anderson, R. P., \& Wilson, S. P. (2009). Quantifying the effectiveness of interactive tutorials in medical library instruction. Medical Reference Services Quarterly, 28(1), 10-21. https://doi.org/10.1080/ 02763860802615815

Andretta, S. (2005). Information literacy: A practitioner's guide. https://doi.org/ 10.1533/9781780630755

Arsyad, A. (2016). Media pembelajaran (Revisi). Jakarta: Rajawali Pers.

Bernacki, M. L., Greene, J. A., \& Crompton, H. (2020). Mobile technology, learning, and achievement: Advances in understanding and measuring the role of mobile technology in education. Contemporary Educational Psychology, 60, 101827. https://doi.org/10.1016/j.cedpsych. 2019.101827

Carrick Enterprises, I. (2012). Project Standardized Assessment of Information Literacy Skills (SAILS). Retrieved from Project SAILS website: www.projectsails.org/site/ the-test/

Crompton, H. (2013). A historical overview of M-learning. In Handbook of Mobile Learning. https://doi.org/10.4324/ 9780203118764.ch1

Dancey, C. P., \& Reidy, J. (2011). Statistics without maths for psychology (5th ed.). New Jersey: Prentice Hall.

Danish, J., \& Hmelo-Silver, C. E. (2020). On activities and affordances for mobile learning. Contemporary Educational $\begin{array}{lll}\text { Psychology, } & \text { 60, } & 101829 .\end{array}$ 
https://doi.org/10.1016/j.cedpsych. 2019.101829

Duderstadt, J. J., \& Womack, F. W. (2004). The future of the public university in America: Beyond the crossroads. Google Books

Dziuban, C., Graham, C. R., Moskal, P. D., Norberg, A., \& Sicilia, N. (2018). Blended learning: the new normal and emerging technologies. International Journal of Educational Technology in Higher Education, 15(1), 1-16. https://doi.org/10. 1186/s41239-017-0087-5

Evans, C. (2008). The effectiveness of mlearning in the form of podcast revision lectures in higher education. Computers \& Education, 50(2), 491-498. https://doi.org/10. 1016/j.compedu.2007.09.016

Fauziah, G., \& Lestari, A. W. (2018). Movement civilization of information literacy at primary school in Tangerang Selatan. Edulib: Journal of Library and Information Science, 8(2), 167-179.

Fernández-Ramos, A. (2016). Online library tutorials in Mexican universities: presence and characteristics. Library Hi Tech, 34(4), 787-802. https://doi.org/10.1108/LHT-082016-0094

Fernández-Ramos, A. (2019). Online information literacy instruction in Mexican university libraries: The librarians' point of view. The Journal of Academic Librarianship, 45(3), 242-251. https://doi.org/10.1016/ j.acalib.2019.03.008

Fraenkel, J. R., Wallen, N. E., \& Hyun, H. H. (2018). How to design and evaluate research in education. New York: McGraw-Hill Education.

Haber, N., \& Mitchell, T. N. (2017). Using formative \& summative assessment to evaluate library instruction in an online first year writing course. Journal of Library \& Information Services in Distance Learning, 11(34), 300-313. https://doi.org/10. 1080/1533290X.2017.1324549

Hasugian, J. (2008). Urgensi literasi informasi dalam kurikulum berbasis kompetensi di Perguruan Tinggi. Pustaha: Jurnal Studi Perpustakaan Dan Informasi, 4(2), 34-44. Retrieved from http://jurnalindustri .petra.ac.id/index.php/pus/article/ download/17231/17184

Hisle, D., \& Webb, K. (2017). Information literacy concepts: An open educational resource. North Carolina: Joyner Library.

Indriani, T. M., Fathoni, T., \& Riyana, C. (2018). Implementasi blended learning dalam program pendidikan jarak jauh pada jenjang pendidikan menengah kejuruan. EDUCATIONAL TECHNOLOGIA, 2(2), 129-139. Retrieved from https://ejournal.upi. edu/index.php/edutechnologia/arti cle/view/19668

Kaustubh A., J., Yogita H., K., Mayuri V., M., \& Pooja G., N. (2017). Android based e-learning application "Class-E." International Research Journal of Engineering and Technology, 4(3), 1745-1748. Retrieved from https://www.irjet.net/archives/V4/i 3/IRJET-V4I3400.pdf

Lin, X., Deng, C., Hu, Q., \& Tsai, C. (2019). Chinese undergraduate students' perceptions of mobile learning: Conceptions, learning profiles, and approaches. Journal of Computer Assisted Learning, 35(3), 317-333. https://doi.org/10.1111/jcal.12333

Lutze, R., \& Waldhor, K. (2015). A smartwatch software architecture for health hazard handling for elderly people. 2015 International Conference on Healthcare Informatics, 356-361. https://doi. org/10.1109/ICHI.2015.50

Maddison, T., Doi, C., Lucky, S., \& Kumaran, M. (2017). Literature review of online learning in academic libraries. In Distributed Learning (pp. 13-46). https://doi.org/10.1016/B978-0-08100598-9.00002-7

Maesyarah, M., Jufri, A. W., \& Kusmiyati, K. (2015). Analisis penguasaan konsep dan miskonsepsi biologi dengan teknik modifikasi certainty of response index pada siswa SM sekota Sumbawa Besar. JURNAL PIJAR MIPA, 1O(1), 1-6. https://doi.org/10. 29303/jpm.v10i1.8

Munir. (2017). Pembelajaran digital. Bandung: Alfabeta.

Muqarrobin, T. F., \& Kuswanto, H. (2016). Development of an android-based physics e-book to ease students' physics learning and its influence on 
their learning achievement. American Journal of Engineering Research, 5(10), 223-229. Retrieved from http://www.ajer.org/papers/ v5(10)/ZE05010223229.pdf

Muyaroah, S., \& Fajartia, M. (2017). Pengembangan media pembelajaran berbasis android dengan menggunakan aplikasi adobe flash CS 6 pada mata pelajaran biologi. Innovative Journal of Curriculum and Educational Technology, 6(2), 22-26. Retrieved from https://journal.unnes.ac.id/sju/ind ex.php/ujet/article/view/19336

OECD. (2005). Are students ready for a technology-rich world? What PISA studies tell us. Retrieved from http://www.oecd.org/education/sch ool/programmeforinternationalstud entassessmentpisa/35995145.pdf

Pedró, F. (2006). The new millennium learners: Challenging our view son ICT and learning. Retrieved from https://publications.iadb.org/public ations/english/document/The-NewMillennium-Learners-Challengingour-Views-on-ICT-and-Learning.pdf

Pew Research Center. (2019). Mobile fact sheet. Retrieved from https://www.pewresearch.org/inter net/fact-sheet/mobile/

Phillips, M., Van Epps, A., Johnson, N., \& Zwicky, D. (2018). Effective engineering information literacy instruction: A systematic literature review. The Journal of Academic Librarianship, 44(6), 705-711. https://doi.org/10.1016/j.acalib.20 18.10.006

Prensky, M. (2001). Digital natives, digital immigrants part 2: Do they really think differently? On the Horizon, 9(6), 1-6. https://doi.org/10.1108/ 10748120110424843

Ramdani, R., Rahmat, M., \& Fakhruddin, A. (2018). Media pembelajaran elearning dalam pembelajaran pendidikan agama islam di SMA Laboratorium Percontohan UPI Bandung. TARBAWY: Indonesian Journal of Islamic Education, 5(1), 47-59. https://doi.org/10.17509/ t.v5i1.13332

Rattanawongsa, R., \& Koraneekij, P. (2015). A development of blended information literacy learning web for Thai High School Students. Procedia - Social and Behavioral Sciences, 174, 2693-2699. https://doi.org/10.1016/j.sbspro.20 15.01 .954

Sadioğlu, Ö., İpek, N., \& Derman, M. T. (2009). Determining the information literacy skills of teacher candidates for the sustainability of quality in education. Procedia - Social and Behavioral Sciences, 1(1), 14551459. https://doi.org/10.1016/ j.sbspro.2009.01.256

Saunders, L. (2018). Information literacy in practice: Content and delivery of library instruction tutorials. The Journal of Academic Librarianship, 44(2), 269-278. https://doi.org/10. 1016/j.acalib.2017.12.022

Sharples, M. (2000). The design of personal mobile technologies for lifelong learning. Computers \& Education, 34(3-4), 177-193. https://doi.org/ 10.1016/S0360-1315(99)00044-5

Sholeh, M., Sutanta, E., \& Sulistyowati, S. (2017). Designing english rush game as an android-based english learning media for primary school students. International Journal of Computer Techniques, 4(5), 31-35. Retrieved from http://www.ijctjournal.org/ Volume4/Issue5/IJCT-V4I5P7.pdf

Sung, Y.-T., Lee, H.-Y., Yang, J.-M., \& Chang, K.-E. (2019). The quality of experimental designs in mobile learning research: A systemic review and self-improvement tool. Educational Research Review, 28, 100279. https://doi.org/10.1016/ j.edurev.2019.05.001

Suprapto, P. K., Suharsono, Chaidir, D. M., \& Ali, M. (2019). Development of wimba 3 dimension interactive animation media on plant anatomy. Journal of Physics: Conference Series, 1233, 012002. https://doi.org/10. 1088/1742-6596/1233/1/012002

Szadziewska, A., \& Kujawski, J. (2017). Advantages and disadvantages of the blended-learning method used in the educational process at the faculty of management at the University of Gdansk, in the opinion of undergraduate students. 10th Annual International Conference of Education, Research and Innovation, 3938-3946. 
https://doi.org/10.21125/iceri.2017 .1051

Webber, S., \& Johnston, B. (2017). Information literacy: conceptions, context and the formation of a discipline. Journal of Information Literacy, 11(1), 156-183. https://doi.org/10.11645/11.1.2205

Wood, D., Bruner, J. S., \& Ross, G. (1976). The role of tutoring in problem solving. Journal of Child Psychology and
Psychiatry, 17(2), 89-100. https://doi.org/10.1111/j.14697610.1976.tb00381.x

Yang, S. Q., \& Chou, M. (2014). Promoting and teaching information literacy on the internet: Surveying the web sites of 264 academic libraries in North America. Journal of Web Librarianship, 8(1), 88-104. https://doi.org/10.1080/19322909. 2014.855586 